\title{
The yellow folder
}

$\mathrm{T}$ he yellow folder sat on the table between us. It was the white elephant in the room, acting simultaneously as a beacon and an omen. I watched as her weathered hands fingered its edges tremulously and lovingly at the same time. I couldn't help myself from staring at the topography of those hands born from eight decades of toil. I concentrated on the tortuous pattern of veins, of spots in various hues of brown, the knobbiness of the fingers, the skin so thin as to be translucent. The hands that touched another soul like no other. The hands shaped by life's offerings.

"This has been such a great help," she said, making reference to the folder.

"I'm glad this plan is working out much better," I replied. It was an automatic response. Said efficiently but with no less intention. I hoped she could see my sincerity through the layers of clinical efficiency that many years of wearing a white coat had instilled.

"I can't tell you what it means to us. Now I know what to do. I won't be calling the ambulance anymore. I know whom to call. I know who will have time to talk to me. It's all here in the folder. Everything we need to do. Everyone we need to contact. The nurse from Health Links helped me put it together. I keep it with me everywhere we go. Even the funeral home knows about us, though I hope they don't think we'll need them anytime soon."

We both knew in the unspoken language that transpires between people that this was more of a wish than a certainty.

Then her blue eyes lit up and the deep furrows around them crinkled as a smile broke out over her face. Revealing perfect white teeth, so at odds with the changes of time seen in her face. The work of a skilled dentist. The last telltale signs of youthful vanity.

"This time it'll be me who kills him, not them." A pause in the conversation

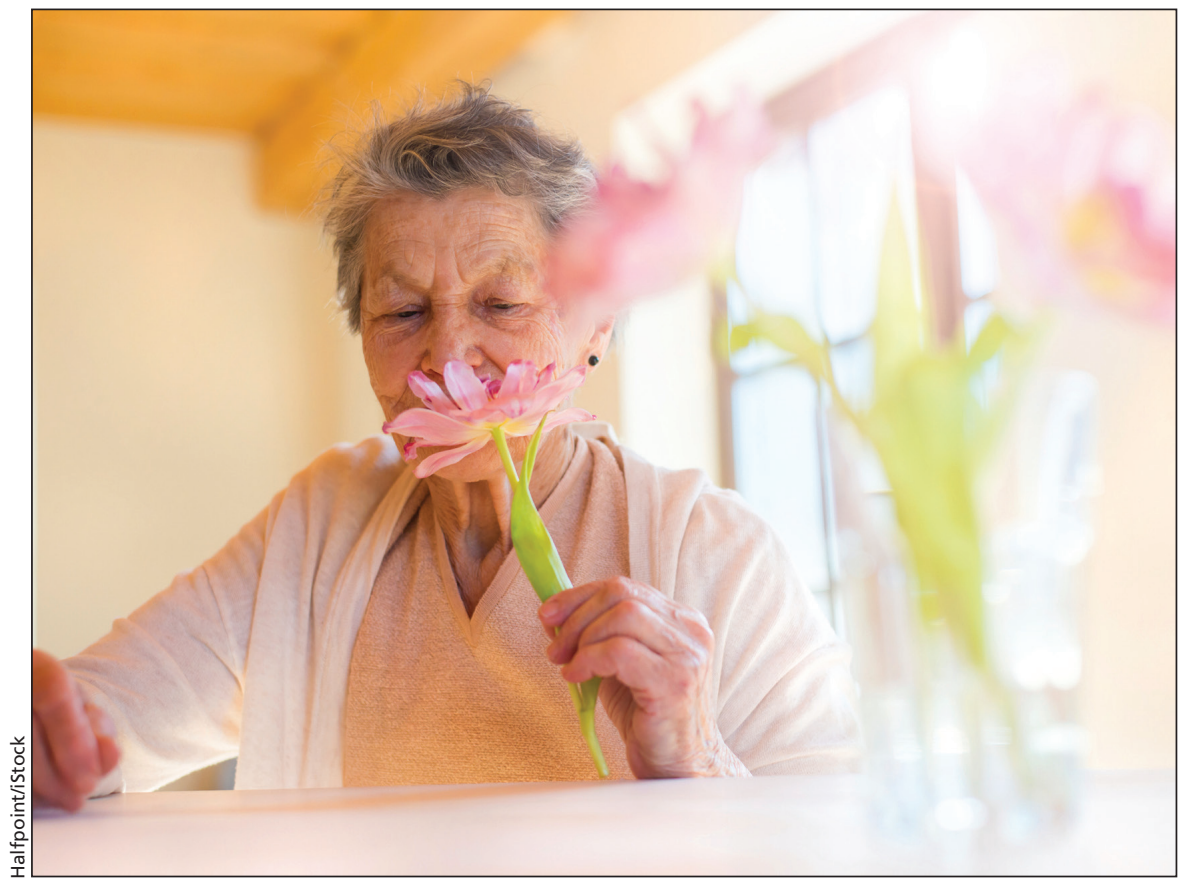

to digest her words. Then she added, "I don't mean that quite the way it sounded, but I'm sure you understand."

Understand I did. She laboured under the pressure to keep her octogenarian husband with dementia out of hospital, ignoring the obvious frailty of her own body. She had succeeded. Many hospital admissions ago, her husband had been given a dire prognosis. Her care, her perseverance, her love had beaten those odds. She had refused to have him committed to a nursing home. She had brought him home each time. She had exhausted whatever limited help was available to her from a system ill-equipped to deal with care for the chronically ill at home. She had exhausted herself.

We both knew the next time he likely could not come home. Not because of his infirmity ... but because of hers. She wasn't describing a new struggle. It was one I had witnessed many times before. Yet this time I felt a sense of outrage at the unfairness of the situation coupled with a sadness that surprised me. The carefully programmed pattern was unravelling. It was uncomfortable. Something I instinctively shied away from.

I started to say, "I know this is difficult for you. Peter may seem to be coping, but his mind is failing him and now his body is too. It's too much for you. We need to plan for his care ... and yours."

However, the words wouldn't come. Platitudes. They got stuck in my throat and I could not lend my voice to them. They somehow seemed inadequate to express the decay in the natural order that had become her life. Two elderly people joined by decades of matrimony, continuing to live together in their own home despite restrictions on both of them to carry out basic activities of living. His impairments outstripping hers. Her health needs beginning to catch up with his. Unrealistic demands placed on the healthier of the two. Even though both had difficulty navigating their 
home, hers was physical, his was cognitive. A relationship changed from longstanding spousal partnership to that of nurse, maid, caregiver and staunch advocate. Every available community resource for advanced home care activated and yet somehow not enough. Years of negative interactions with acute care admissions and nursing home respite care leading to a belief that living at home without help was preferable to institutional care.

"Dear," she said patting my hand with hers, "it's such a joy to talk to you. I feel better when we talk. But we both know the truth. I just need help accepting it."

And there it was. The health care agenda for today's visit: acceptance. So much more difficult than treating the acute care needs. Infection, cardiorespiratory illness, chronic musculoskeletal disease, failure to thrive, dementia: for these conditions I had a plan. Acceptance of the situation had no algorithmic menu to choose from. No hard data to fall back on. No clinical practice guidelines to support the treatment. No scientific trappings to buttress the difficult decisions that had to be made. It was time to remove the white coat.

We sat in her kitchen, over a cup of coffee, discussing her strategy and attempting to answer daunting questions. What resonated with her? What could she realistically manage now that her health was deteriorating? Could her family offer any more assistance? This time I was not in charge of a treatment plan. This time I was supporting and gently guiding her decisions. Enabling her to navigate through a health care system with scarce reserves. Adding to the yellow folder.

By the end of the encounter, we had made some progress. Yet I left the visit with a lingering sense of melancholy. Instinctively, I knew that all too soon there would be another yellow folder. This time it would have her name on it instead of his.

\section{Zahra Bardai MD MHSc}

Woodbridge Medical Centre Family Health Team, Woodbridge, Ont.;

Department of Family and Community Medicine, University of Toronto, Toronto, Ont.; Department of Family Medicine, McMaster University, Hamilton, Ont.

This is based on a true story. The patient has given consent for this story to be told.

\section{CMAJ 2015. DOI:10.1503/cmaj.150524}

This article placed second in the prose category of The 2015 Humanities Poetry and Prose Contest, jointly sponsored by ARS Medica and CMAJ. 